\title{
PENGARUH SUBTITUSI TEPUNG DAUN KELOR (Moringa oleifera Lam.) TERHADAP SIFAT ORGANOLEPTIK DAN KADAR KALSIUM SNACK BAR
}

\author{
The Substitution Effect Of Moringa Leaves Flour (Moringa oleifera Lam.) \\ To Calcium Levels And Accept Power Of The Snack Bar
}

\author{
Nur Fahlia ${ }^{1}$, Septiani $^{2}$ \\ ${ }^{1.2}$ Program Studi Gizi, Fakultas Kesehatan Masyarakat, Universitas Binawan \\ Email korespondensi: septiani@binawan.ac.id
}

\begin{abstract}
Sources of calcium in food are found, among others, in milk and its processed products and green vegetables such as Moringa oleifera Lam. Moringa leaves are rich in nutritious nutrients and can be used for health, The application of Moringa leafflour in the processing of food products is finite. Moringa leaves are rich in nutritious nutrients and can be used for health, The application of Moringa leaf flour in the processing of food products is finite. This research aims to analyze the effect of the substitution of Moringa leaf flour on the snack bar. Snack bar is a type of snack in the form of bars, derived from various ingredients and other food mixture ingredients such as cereals and nuts types. This experimental research design uses a Completely randomized design (CRD) with one control formula and three substitution levels including FO (100\% wheat flour), F1 (95\% wheat flour and 5\% Moringa leaves flour), F2 (90\% wheat flour and 10\% Moringa leaves flour) and F3 (85\% wheat flour and 15\% moringa leaves flour. Data from organoleptic test results were analyzed using the ANOVA test if there are significant differences followed by Duncan's further tests. While the results of proximate levels and calcium levels were analyzed using an independent $t$-test While the results of proximate levels and calcium levels were analyzed using an independent $t$-test. The organoleptic analysis of the hedonic test showed that the selected snack bar formula was $F 2$. The results of the proximate analysis of selected snack bars contains $12.52 \%$ water, $1.65 \%$ ash, $19.61 \%$ fat, $9.23 \%$ protein, $56.99 \%$ carbohydrate, and $344.14 \mathrm{mg}$ $1100 \mathrm{~g}$ calcium. The contribution of selected snack bar energy is 441.37 kcal per 100 grams and 203.03 kcal per serving size (46 gram). This research concludes that the control formula snack bar is significant differences from the selected snack bar formula ( $p<0.05)$ in in each analysis (water, ash, fat, protein, carbohydrate, and calcium).
\end{abstract}

Keywords: calcium, moringa leaves, snack bar, substitution

\begin{abstract}
ABSTRAK
Sumber kalsium dalam pangan ditemukan antara lain pada susu dan produk olahannya serta sayuran hijau seperti daun kelor (Moringa oleífera Lam.). Daun kelor kaya akan zat gizi yang berkhasiat dan dapat dimanfaatkan bagi kesehatan tubuh, penggunaan tepung daun kelor dalam pengolahan produk pangan masih sangat terbatas. Penelitian ini bertujuan untuk menganalisis pengaruh subtitusi tepung daun kelor pada snack bar. Snack bar merupakan salah satu jenis makanan ringan dengan bentuk batangan, berasal dari berbagai bahan dasar dan bahan campuran pangan lainnya bahan seperti jenis sereal, dan jenis kacang-kacangan Desain penelitian ekperimental ini menggunakan Rancangan Acak Lengkap (RAL) dengan satu formula kontrol dan tiga tingkatan subtitusi antara lain F0 (100\% tepung terigu), F1 ( $95 \%$ tepung terigu dan 5\% tepung daun kelor), F2 (90\% tepung terigu dan 10\% tepung daun kelor) dan F3 (85\% tepung terigu dan $15 \%$ tepung daun kelor). Data hasil uji organoleptik dianalisis mengunakan uji ANOVA, apabila signifikan dilanjutkan dengan uji lanjut duncan. Sedangkan hasil kadar proksimat dan kadar kalsium dianalisis menggunakan uji independent $t$-test. Hasil analisis organoleptik uji hedonik menunjukkan snack bar formula terpilih yaitu F2. Hasil analisis proksimat snack bar terpilih mengandung kadar air 12,52\%, kadar abu 1,65\%, lemak 19,61\%, protein 9,23\%, karbohidrat 56,99\%, serta kadar kalsium sebesar 344,14 mg/100g. Kontribusi energi snack bar terpilih sebesar 441,37 kkal per 100 gram dan 203,03 kkal per takaran saji (46 gram). Kesimpulan penelitian ini adalah snack bar formula kontrol berbeda nyata dengan snack bar formula terpilih $(\mathrm{p}<0,05)$ pada semua uji sifat kimia (kadar air, kadar abu, lemak, protein, karbohidrat, dan kadar kalsium)
\end{abstract}

Kata kunci: daun kelor, kalsium, snack bar, subtitusi 
J.Gipas, November 2020, Volume 4 Nomor 2

ISSN 2599-0152 eISSN 2599-2465

http://jos.unsoed.ac.id/index.php/jgps

\section{PENDAHULUAN}

Daun kelor kaya akan zat gizi yang berkhasiat dan dapat dimanfaatkan bagi kesehatan tubuh. Daun Kelor mengandung zat gizi antara lain setara dengan 7 kali vitamin $\mathrm{C}$ dalam jeruk, setara dengan 4 kali vitamin A dalam wortel, setara dengan protein dalam 2 yoghurt, dan setara dengan 4 gelas kalsium dalam susu (Mahmood et al, 2011). Pada daun kelor segar terdapat kalsium sebesar $440 \mathrm{mg}$, dan pada daun kelor kering sebesar $2.003 \mathrm{mg}$ masing-masing per 100 g/porsi (Bey, 2010). Terjadinya peningkatan kandungan kalsium, nilai kalori, zat besi, dan vitamin A pada daun kering dan pengolahannya menjadi tepung atau sejenis bubuk disebabkan adanya pengurangan kadar air daun kelor dengan metode pengeringan (Zakaria et al., 2011).

Daun kelor jarang sekali dimanfaatkan oleh masyarakat sebagai bahan baku untuk pengolahan makanan, penelitian sebelumnya pemanfaatan bubuk daun kelor baru diolah dalam bentuk biskuit (Pratiwi K, 2018), tidak seperti halnya ampas kelapa yang sudah dimanfaatkan menjadi tepung ampas kelapa (Rousmaliana dan Septiani, 2019) dan diolah menjadi brownies kukus (Hiyanah dan Septiani, 2019) dan kulit pisang kepok yang bisa dijadikan tepung kulit pisang kepok (Serly dan Septiani, 2019) yang dapat dijadikan snack bar (Afifah dan Srimiati, 2020), Oleh karena itu penelitian terhadap formulasi snack bar dengan substitusi tepung daun kelor sebagai alternatif untuk mengembangkan bahan pangan lokal menjadi bahan baku pangan fungsional dan bermanfaat bagi kesehatan

\section{METODE}

Desain penelitian yang di gunakan yaitu Rancangan Acak Lengkap (RAL) dengan faktor tunggal dan $2 \mathrm{x}$ pengulangan. Penelitian dilakukan pada bulan Januari April 2020 yang bertempat di Laboratorium Kuliner Universitas Binawan, Jakarta dan di Laboratorium Saraswanti Indo Genetech, Bogor.

Alat dan bahan yang digunakan pada penelitian ini adalah, panci, mesin cabinet drying, blender, ayakan 80 mesh, timbangan, daun kelor, gula halus, wijen, kismis, susu bubuk, air mineral, kacang tanah, dan margarin.

Variabel bebas (independen) dalam penelitian ini adalah persentase formula substitusi bubuk daun kelor dan tepung terigu dengan F1 sebanyak 95\% tepung terigu dan 5\% tepung daun kelor, F2 sebanyak 90\% tepung terigu dan 10\% tepung daun kelor, F3 sebanyak $85 \%$ tepung terigu dan $15 \%$ tepung daun kelor dan untuk perbandingan dibuat 
formula kontrol F0 sebanyak 100\% tepung terigu dan $0 \%$ tepung daun kelor. Variabel terikat (dependen) dalam penelitian ini hasil pengujian organoleptik (hedonik dan mutu hedonik), analisis kadar proksimat dan analisis kadar kalsium

\section{Pembuatan Tepung daun kelor}

Tahap pertama pembuatan tepung daun kelor adalah penyortian daun kelor segar, dicuci pada air mengalir, di blanching selama 1 menit dengan suhu $100^{\circ} \mathrm{C}$ dan ditiriskan. Tahap selanjutnya pengeringan di dalam cabinet drying selama 8 jam dengan suhu 30$35^{\circ} \mathrm{C}$. Daun kelor yang sudah kering dihancurkan menggunakan blender dan diayak dengan ayakan 80 mesh. Tepung daun kelor disimpan di wadah kedap udara.

\section{Pembuatan Snack Bar}

Pembuatan snack bar dilakukan dengan pemilahan bahan terlebih dahulu, yaitu pencampuran bahan kering dan pencampuran bahan basah. Pencampuran bahan kering terdiri dari tepung terigu, tepung daun kelor, susu bubuk, kacang tanah cacah, wijen dan kismis. Sementara pencampuran bahan basah terdiri dari margarin, garam, dan gula halus. Setelah masing-masing jenis pencampuran telah teraduk rata, kedua jenis pencampuran bahan kering dan bahan basah digabungkan dengan menambahkan air lalu di aduk kembali higga adonan merata. Adonan lalu dicetak dengan bentuk persegi panjang dan diletakkan dalam loyang alumunium. Setelah itu di panggang dalam oven dengan suhu $100^{\circ} \mathrm{C}$ selama 40 menit, dan pemanggangan lanjut dengan menaikkan suhu hingga $120^{\circ} \mathrm{C}$ selama 20 menit.

Alat pengumpul data organoleptik yang digunakan adalah berupa kuesioner uji organoleptik, mencakup uji hedonik dan uji mutu hedonik yang diisi oleh panelis semi terlatih sebanyak 30 orang. Parameter yang akan diamati dalam penelitian ini meliputi data hasil uji hedonik dan uji mutu hedonik, análisis proksimat, dan kalsium. Uji hedonik meliputi tingkat kesukaan panelis terhadap rasa, aroma, tekstur, warna. Penilaian dilakukan dengan menggunakan skor 1 sampai 5 dengan kriteria yang telah ditentukan seperti: sangat tidak suka (1), tidak suka (2), biasa saja (3), suka (4), dan sangat suka (5). Sedangkan uji mutu hedonik memiliki sifat yang lebih spesifik yaitu menyatakan kesan baik atau buruk terhadap rasa aroma, tekstur, dan warna produk.

Pengolahan data pada penelitian ini menggunakan Microsoft Excel 2010 dan program statistik komputer. Data hasil uji hedonik dan uji mutu hedonik, dianalisis dengan deskriptif, selanjutnya diuji statistik menggunakan Analysis of Variance 
J.Gipas, November 2020, Volume 4 Nomor 2

ISSN 2599-0152 eISSN 2599-2465

http://jos.unsoed.ac.id/index.php/jgps

(ANOVA). Jika ANOVA menunjukkan pengaruh pelakuan nyata, maka dilanjutkan dengan Duncan's Multiple Range Test untuk mencari keberadaan perbedaan dari pelakuan yang ada. Data hasil uji kontrol dan formula terpilih kadar proksimat dan kadar kalsium dianalisis menggunakan uji beda (Independent Sample T-test). Penelitian ini telah mendapat persetujuan komite etik (exemted) dengan nomor: 15/XII/2019/KEPK.

HASIL DAN PEMBAHASAN

\section{A. Uji Organoleptik Snack Bar Tepung daun kelor}

Formulasi snack bar tepung daun kelor yang telah dibuat selanjutnya dilakukan uji organoleptik. Penilaian sensoris dari masingmasing atribut dianalisis menggunakan uji sidik ragam (ANOVA), kemudian dilanjutkan dengan uji lanjut duncan. Hasil uji organoleptik berupa uji hedonik disajikan pada tabel 1 dan uji mutu hedonik disajikan pada tabel 2 .

Tabel 1. Hasil Uji Hedonik Snack Bar Subtitusi Tepung Daun Kelor

\begin{tabular}{lccccc}
\hline \multirow{2}{*}{ Formula } & \multicolumn{5}{c}{ Atribut } \\
\cline { 2 - 5 } & Rasa & Tekstur & Warna & Aroma & Keseluruhan \\
\hline F0 (0\%) & $4,10^{\mathrm{d}}$ & $3,95^{\mathrm{b}}$ & $4,15^{\mathrm{c}}$ & $4,12^{\mathrm{c}}$ & $4,08^{\mathrm{d}}$ \\
F1 (05\%) & $2,85^{\mathrm{b}}$ & $3,27^{\mathrm{a}}$ & $3,53^{\mathrm{b}}$ & $3,20^{\mathrm{b}}$ & $3,21^{\mathrm{b}}$ \\
F2 (10\%) & $3,55^{\mathrm{c}}$ & $3,78^{\mathrm{b}}$ & $3,42^{\mathrm{b}}$ & $3,03^{\mathrm{b}}$ & $3,45^{\mathrm{c}}$ \\
F3 (15\%) & $2,20^{\mathrm{a}}$ & $3,15^{\mathrm{a}}$ & $2,80^{\mathrm{a}}$ & $2,23^{\mathrm{a}}$ & $2,60^{\mathrm{a}}$ \\
\hline
\end{tabular}

Keterangan: Skala atribut yaitu 1 = sangat tidak suka hingga 5 = sangat suka

: Huruf yang beda pada baris yang sama menunjukkan perbedaan yang nyata $(\mathrm{p}<0,05)$

Berdasarkan Tabel 1, Hasil uji lanjut Duncan menunjukkan terdapat perbedaan yang nyata pada setiap konsentrasi snack bar subtitusi tepung daun kelor terhadap atribut rasa dan keseluruhan. Sementara lain, pada atribut tekstur F0 dan F2 tidak berbeda nyata, namun berbeda nyata dengan F1 dan F3. Untuk atribut warna dan aroma F1 dan F2 tidak berbeda nyata, namun F1 dan F2 berbeda nyata dengan F0 dan F3

Tabel 2. Hasil Uji Mutu Hedonik Snack Bar Subtitusi Tepung Daun Kelor 


\begin{tabular}{ccccc}
\hline \multirow{2}{*}{ Formula } & \multicolumn{5}{c}{ Atribut } \\
\cline { 2 - 5 } & Rasa & Tekstur & Warna & Aroma \\
\hline F0 (0\%) & $3,83^{\mathrm{c}}$ & $3,48^{\mathrm{b}}$ & $4,87^{\mathrm{d}}$ & $3,97^{\mathrm{c}}$ \\
F1 (05\%) & $3,08^{\mathrm{b}}$ & $3,18^{\mathrm{a}}$ & $2,97^{\mathrm{c}}$ & $3,10^{\mathrm{b}}$ \\
F2 (10\%) & $3,18^{\mathrm{b}}$ & $3,40^{\mathrm{ab}}$ & $2,12^{\mathrm{b}}$ & $3,00^{\mathrm{b}}$ \\
F3 $(15 \%)$ & $2,13^{\mathrm{a}}$ & $3,20^{\mathrm{a}}$ & $1,15^{\mathrm{a}}$ & $1,95^{\mathrm{a}}$ \\
\hline
\end{tabular}

Keterangan: Atribut rasa skala $1=$ sangat pahit hingga $5=$ sangat manis,

Atribut tekstur skala $1=$ sangat keras hingga $5=$ sangat lembut,

Atribut warna skala $1=$ hijau tua sampai $5=$ kuning muda,

Atribut aroma skala $1=$ sangat langu sampai $5=$ sangat wangi.

: Huruf yang beda pada baris yang sama menunjukkan perbedaan yang nyata $(\mathrm{p}<0,05)$.

\section{Rasa}

Rasa merupakan penentu tingkat kesukaan dan daya terima konsumen terhadap suatu produk. Berdasarkan Tabel 2, hasil uji mutu hedonik terhadap atribut rasa, menunjukkan snack bar F3 memiliki rasa agak pahit, sedangkan F0, F1 dan F2 memiliki rasa biasa saja.

Hasil uji ANOVA menunjukkan bahwa perbedaan snack bar substitusi tepung daun kelor berpengaruh nyata $(\mathrm{p}<0,05)$ terhadap mutu hedonik pada atribut rasa. Hasil uji lanjut Duncan menunjukkan bahwa perbedaan konsentrasi pada snack bar F1 dan F2 tidak berbeda nyata, namun F0 dan F3 berbeda nyata, sedangkan F1 dan F2 dengan F0 dan F3 memberikan perbedaan yang nyata $(\mathrm{p}<0,05)$ terhadap atribut penilaian rasa.

Rasa snack bar akan terasa pahit seiring penambahan dan peningkatan konsentrasi tepung daun kelor yang digunakan. Hal ini sejalan dengan beberapa penelitian seperti penelitian Pratiwi, K (2018) mengenai pembuatan cookies, dan Darmawan (2017) mengenai bakpao berbasis daun kelor. Saponin pada daun kelor menghasilkan rasa pahit, memiliki karakteristik berupa busa dan mudah larut dalam air (Indriasari et al., 2016).

\section{Tekstur}

Tekstur adalah salah satu komponen dari penilaian uji sensoris dengan memanfaatkan rongga mulut dan indra peraba seperti jarijemari tangan (Setyaningsih et al., 2010). Hasil uji mutu hedonik terhadap atribut tekstur menunjukkan snack bar F0, F1, F2, dan F3 memiliki tekstur yang biasa, tidak cenderung keras dan tidak cenderung lembut. Hasil uji ANOVA menunjukkan bahwa perbedaan tingkat substitusi tepung daun kelor berpengaruh nyata $(\mathrm{p}<0,05)$ terhadap mutu hedonik pada atribut tekstur.

Hasil uji lanjut Duncan menunjukkan bahwa perbedaan konsentrasi pada snack bar 
J.Gipas, November 2020, Volume 4 Nomor 2

ISSN 2599-0152 eISSN 2599-2465

http://jos.unsoed.ac.id/index.php/jgps

F0 dan F1 berbeda nyata, sedangkan F2 tidak berbeda nyata dengan F0 dan F1, serta F1 dan F3 tidak berbeda nyata terhadap atribut penilaian tekstur. Hasil ini sesuai dengan peneilitian Pratiwi, F (2018) bahwa beberapa persentase subtitutisi tepung daun kelor pada produk food bar tidak memberikan pengaruh yang nyata terhadap atribut tekstur.

\section{Warna}

Warna adalah bagian penting yang menjadi ciri visual sebuah produk (Lyons dan Wien, 2017). Hasil uji mutu hedonik terhadap atribut warna menunjukkan bahwa snack bar F0 berwarna cenderung kuning muda, F1 berwarna cenderung hijau muda, F2 berwarna cenderung hijau, sedangkan snack bar $\mathrm{F} 3$ berwarna hijau tua.

Hasil uji ANOVA menunjukkan bahwa perbedaan tingkat substitusi tepung daun kelor berpengaruh nyata $(\mathrm{p}<0,05)$ terhadap mutu hedonik pada atribut penilaian warna. Hasil uji lanjut Duncan menunjukkan bahwa perbedaan konsentrasi pada keempat formulasi snack bar subtitusi tepung daun kelor masing-masing formulasi memberikan perbedaan yang nyata terhadap atribut penilaian warna.

Hasil atribut penilaian warna dalam penilitian ini sejalan dengan penelitian yang dilakukan oleh Pratiwi, F (2018) tentang formulasi food bar dari tepung daun kelor dan tepung ikan lele, bahwa presentase subtitusi tepung daun kelor yang tinggi mempengaruhi kenampakan warna food bar menjadi hijau lebih gelap. Hal tersebut menandakan adanya kandungan pigmen hijau atau senyawa klorofil dalam tanaman daun kelor. Daun kelor mengandung klorofil pada $6.890 \mathrm{mg} / \mathrm{kg}$ bahan kering (Krisnadi, 2015).

\section{Aroma}

Hasil uji mutu hedonik terhadap atribut aroma menunjukkan bahwa snack bar F0 beraroma cenderung wangi, untuk snack bar F1 dan F2 beraroma biasa, untuk snack bar F3 beraroma langu. Hasil uji ANOVA menunjukkan bahwa perbedaan tingkat substitusi tepung daun kelor berpengaruh nyata $(\mathrm{p}<0,05)$ terhadap mutu hedonik pada atribut aroma. Hasil uji lanjut Duncan menunjukkan bahwa perbedaan konsentrasi pada snack bar F1 dan F2 tidak berbeda nyata, namun F1 dan F2 berebeda nyata dengan F0 dan F3, sedangkan F3 dengan F0 memberikan perbedaan yang nyata terhadap atribut penilaian aroma.

Penilaian panelis terhadap atribut aroma semakin rendah selaras dengan penambahan tepung daun kelor yang semakin tinggi. Hal ini sejalan dalam penelitian Majid et al., (2017), mengenai pembuatan flakes dengan penambahan tepung daun kelor menghasilkan aroma khas langu daun kelor. 
J.Gipas, November 2020, Volume 4 Nomor 2

ISSN 2599-0152 eISSN 2599-2465

http://jos.unsoed.ac.id/index.php/jgps

Aroma khas yang tidak sedap pada daun kelor disebabkan karena adanya senyawa saponin, yaitu bagian dari steroid atau triterpenoid glukosida yang terikat pada karbohidrat (Indriasari et al., 2016).

\section{B. Hasil Analisis Proksimat Snack Bar}

Tepung daun kelor Formula Terpilih

Analisis proksimat yang dilakukan adalah kadar air, kadar abu, lemak, protein, dan karbohidrat. Selain analisis proksimat, dilakukan analisis kadar kalsium. Data hasil analisis pada formula terpilih dijelaskan secara deskriptif dan dibandingkan dengan formula kontrol, serta dilakukan uji beda (Independent Sample t-test) untuk mengetahui adanya perbedaan antara formula kontrol dan formula terpilih. Hasil analisis proksimat snack bar formula kontrol dan formula terpilih disajikan pada tabel 3.

Tabel 3. Hasil Analisis Proksimat Snack Bar F0 (0\%) (Kontrol) dan F2 (10\%) (Terpilih)

\begin{tabular}{lccc}
\hline \multicolumn{1}{c}{ Komponen } & Formula Kontrol $(\boldsymbol{\%} \mathbf{b} / \mathbf{b})$ & Formula Terpilih $(\boldsymbol{\%} \mathbf{b} / \mathbf{b})$ & $\boldsymbol{p}$-value \\
\hline Kadar Air & 17,35 & 12,52 & $0,000^{*}$ \\
Kadar Abu & 1,19 & 1,65 & $0,024^{*}$ \\
Lemak & 18,98 & 19,61 & $0,018^{*}$ \\
Protein & 9,02 & 9,23 & $0,005^{*}$ \\
Karbohidrat & 53,46 & 56,99 & $0,000^{*}$ \\
\hline
\end{tabular}

Keterangan: *) perbedaan secara signifikan $(\mathrm{p}<0,05)$

Berdasarkan Tabel 3 Berdasarkan hasil analisis uji beda (Independent Simple T-test), snack bar formula kontrol berbeda nyata dengan snack bar formula terpilih $(\mathrm{p}<0,05)$ pada semua uji sifat kimia (kadar air, kadar abu, lemak, protein, karbohidrat, dan kadar kalsium).

\section{Kadar Air}

Air merupakan salah satu komponen yang seringkali ditemukan dihampir setiap bahan makanan. Berdasarkan tabel 3, hasil analisis kadar air formula kontrol mencapai $17,35 \%$, sedangkan untuk formula terpilih mencapai 12,52\%. Hasil uji beda (Independent Sample t-test) menunjukkan kadar air snack bar tepung daun kelor formula kontrol memiliki perbadaan yang sangat nyata $(\mathrm{p}<0,05)$ dengan snack bar tepung daun kelor formula terpilih.

Hasil analisis tersebut memperlihatkan bahwa penambahan tepung daun kelor sangat berpengaruh terhadap kadar air snack bar, hal serupa juga terjadi dalam penelitian yang dilakukan oleh Pratiwi, K 
J.Gipas, November 2020, Volume 4 Nomor 2

ISSN 2599-0152 eISSN 2599-2465

http://jos.unsoed.ac.id/index.php/jgps

(2018). Tepung daun kelor dapat membuka ikatan hidrogen, sehingga protein mampu mengikat air dan sebagian protein terkoagulasi (Arwani et al., 2019).

\section{Kadar Abu}

Kadar abu menjadi parameter total jumlah mineral yang ada dalam makanan. Hasil analisis menunjukkan kadar abu formula kontrol mencapai 1,19\%, sedangkan untuk formula terpilih mencapai $1,65 \%$. Hasil uji beda (Independent Sample t-test) menunjukkan kadar abu snack bar tepung daun kelor formula kontrol berbeda nyata $(\mathrm{p}<0,05)$ dengan snack bar tepung daun kelor formula terpilih. Dalam penelitian Nurjanah (2017), hasil analisis kadar abu produk torsang snack bar yaitu sebesar 1,85\% (bk), serta penelitian Priyanto dan Nisa (2016) yang melakukan pembuatan mie instan dengan penambahan $10 \%$ tepung daun kelor menghasilkan kadar abu sebesar 1,52\%. Dapat diasumsikan bahwa kadar abu snack bar terpilih dalam penelitian ini tidak jauh berbeda dengan berbagai penelitian tersebut.

\section{Kadar Lemak}

Lemak dalam pengolahan pangan berperan sebagai pelembut adonan, pemberi rasa gurih, dan dapat meningkatkan volume bahan. Karakteristik adonan ditentukan oleh penggunaan jenis lemak yang berbeda (Sari, 2015).
Hasil analisis menunjukkan kadar lemak formula kontrol mencapai 18,98\% sedangkan untuk formula terpilih mencapai $19,61 \%$. Hasil uji beda (Independent Sample t-test) menunjukkan kadar lemak snack bar tepung daun kelor formula kontrol berbeda nyata $(p<0,05)$ dengan snack bar tepung daun kelor formula terpilih. Kadar lemak yang semakin tinggi pada snack bar formula terpilih disebabkan oleh penambahan tepung daun kelor yang semakin banyak. Tepung daun kelor memiliki kadar lemak sebesar 6,74\% (Kurniawati et al., 2018).

\section{Kadar Protein}

Hasil analisis menunjukkan kadar protein formula kontrol mencapai 9,02\% sedangkan untuk formula terpilih mencapai 9,23\%. Hasil uji beda (Independent Sample t-test) menunjukkan kadar protein snack bar tepung daun kelor formula kontrol berbeda nyata $(\mathrm{p}<0,05)$ dengan snack bar tepung daun kelor formula terpilih. Hasil analisis kadar protein snack bar dalam penelitian ini lebih tinggi dibandingkan dengan kadar protein snack bar pada penelitian Nurjanah (2017), yaitu sebesar 7,61\%.

\section{Kadar Karbohidrat}

Penggunaan tepung terigu, gula halus, dan susu bubuk menjadi sumber karbohidrat utama dalam pembuatan food bar (Pratiwi F, 2018). Hasil analisis menunjukkan kadar 
J.Gipas, November 2020, Volume 4 Nomor 2

ISSN 2599-0152 eISSN 2599-2465

http://jos.unsoed.ac.id/index.php/jgps

karbohidrat formula kontrol mencapai $53,46 \%$ sedangkan untuk formula terpilih mencapai 56,99\%.

Hasil uji beda (Independent Sample ttest) menunjukkan kadar karbohidrat snack bar tepung daun kelor formula kontrol memiliki perbadaan yang sangat nyata $(\mathrm{p}<0,05)$ dengan snack bar tepung daun kelor formula terpilih. Kadar karbohidrat snack bar komersil sekitar 45,1-49,9\% (bb) (Natalia, 2010). Hasil analisis kadar karbohidrat snack bar formula terpilih dalam penelitian ini jauh lebih tinggi dibandingkan dengan produk snack bar komersil yang beredar di pasaran. Menurut Kurniawati et al., (2018) tepung daun kelor mengandung karbohidrat sebesar $51,9 \%$ per 100 gram (metode by diff). Sehingga penambahan tepung daun kelor dalam pembuatan snack bar ini dapat menyumbang kadar karbohidrat.

\section{Analisis Kalsium Snack Bar Tepung daun kelor Formula Terpilih}

Kalsium berperan penting dalam proses mineralisasi tulang. Menurut Beto (2015), asupan kalsium yang memadai dapat mengurangi risiko patah tulang dan osteoporosis.

Hasil analisis kalsium dari formula kontrol dan terpilih disajikan pada tabel 4 .

Tabel 4. Hasil Analisis Kadar Kalsium Snack Bar F0 (0\%) (Kontrol) dan F2 (10\%) (Terpilih)

\begin{tabular}{cccc}
\hline Komponen & Formula Kontrol & Frormula Terpilih & $\boldsymbol{p}$-value \\
\hline Kalsium & $129,09 \mathrm{mg} / 100 \mathrm{~g}$ & $344,14 \mathrm{mg} / 100 \mathrm{~g}$ & $0,000^{*}$
\end{tabular}

Keterangan: *) perbedaan secara signifikan $(\mathrm{p}<0,05)$

Berdasarkan tabel 4, hasil analisis kadar kalsium formula kontrol sebesar 129,09 $\mathrm{mg} / 100 \mathrm{~g}$ sedangkan untuk formula terpilih sebesar 344,14 mg/100g. Hasil uji beda (Independent Sample t-test) menunjukkan kadar kalsium snack bar tepung daun kelor formula kontrol memiliki perbadaan yang sangat nyata $(\mathrm{p}<0,05)$ dengan snack bar tepung daun kelor formula terpilih.
Kadar kalsium snack bar komersil sekitar 297-301 mg/100g (Natalia, 2010). Hal ini menunjukkan jika formula snack bar tepung daun kelor formula terpilih memiliki kadar kalsium yang lebih tinggi dibandingkan dengan kadar kalsium produk snack bar komersil, dan kadar kalsium produk snack bar dalam penelitian lainnya seperti pada penelitian Pratiwi, F (2018) yaitu sebesar 294,16 mg/100g, serta pada 
penelitian Nurjanah (2017) yaitu sebesar $109,75 \mathrm{mg} / 100 \mathrm{~g}$.

\section{Kandungan Gizi Snack Bar Tepung daun kelor}

Analasis kandungan energi dan zat gizi yang dilakukan yaitu per 100 gram dan per takaran saji snack bar. Dalam penelitian ini, snack bar dengan subtitusi daun kelor memiliki berat per takaran saji sebesar 46 gram (1 batang). Untuk memenuhi kebutuhan energi dan zat gizi sehari, makanan selingan dapat berkontribusi sekitar $10 \%$ dari total angka kecukupan gizi harian.

Hasil análisis kandungan energi dan zat gizi snack bar per 100 gram serta kontribusi yang diberikan terhadap AKG dan ALG disajikan pada tabel 5 .

Tabel 5. Kandungan Energi dan Zat Gizi Snack Bar per 100 gram dan Kontribusinya terhadap AKG dan ALG

\begin{tabular}{|c|c|c|c|c|c|c|}
\hline \multirow{2}{*}{ Komposisi } & \multicolumn{2}{|c|}{$\begin{array}{l}\text { Kandungan Energi dan } \\
\text { Zat Gizi per } 100 \text { gram }\end{array}$} & \multicolumn{2}{|c|}{$\%$ AKG* } & \multicolumn{2}{|c|}{$\%$ ALG** } \\
\hline & $\begin{array}{l}\text { Formula } \\
\text { Kontrol }\end{array}$ & $\begin{array}{l}\text { Formula } \\
\text { Terpilih }\end{array}$ & $\begin{array}{c}\text { Formula } \\
\text { Kontrol }\end{array}$ & $\begin{array}{c}\text { Formula } \\
\text { Terpilih }\end{array}$ & $\begin{array}{c}\text { Formula } \\
\text { Kontrol }\end{array}$ & $\begin{array}{c}\text { Formula } \\
\text { Terpilih }\end{array}$ \\
\hline Energi (kkal) & 420,74 & 441,37 & 21,03 & 22,07 & 19,57 & 20,53 \\
\hline Lemak (g) & 18,98 & 19,61 & 8,54 & 8,82 & 7,94 & 8,21 \\
\hline Protein $(\mathrm{g})$ & 9,02 & 9,23 & 1,80 & 1,85 & 1,68 & 1,72 \\
\hline Karbohidrat (g) & 53,46 & 56,99 & 10,69 & 11,40 & 9,95 & 10,60 \\
\hline Kalsium (mg) & 129,09 & 344,14 & 12,91 & 34,41 & 11,73 & 31,28 \\
\hline
\end{tabular}

Klaim Gizi merupakan segala bentuk uraian yang menandakan adanya kandungan zat gizi tertentu dalam makanan (BPOM, 2016). Menurut BPOM (2016) suatu produk pangan dapat mencantumkan klaim sumber mineral jika terdapat mineral sebanyak $15 \%$ ALG per 100 gram (dalam bentuk padat). Sementara untuk mememperoleh klaim tinggi/kaya mineral, produk pangan harus memenuhi kandungan mineral sebanyak 2 kali jumlah "sumber".
Berdasarkan pemaparan tersebut, produk snack bar tepung daun kelor formula terpilih dapat dikatakan sebagai makanan kaya akan kalsium, karena memenuhi klaim tinggi/kaya mineral yaitu mencapai 31,28\% ALG per 100 gram (dalam bentuk padat).

Hasil analisis kandungan energi dan zat gizi snack bar per takaran saji (46 gram) serta kontribusi yang diberikan terhadap AKG dan ALG disajikan pada tabel 6. 
Tabel 6. Kandungan Energi dan Zat Gizi Snack Bar per Takaran Saji (46 gram) dan Kontribusinya terhadap AKG dan ALG

\begin{tabular}{lcccccc}
\hline & \multicolumn{3}{c}{$\begin{array}{c}\text { Kandungan Energi dan } \\
\text { Zat Gizi per takaran }\end{array}$} & \multicolumn{2}{c}{ \%AKG* } & \multicolumn{2}{c}{ \%ALG** } \\
\cline { 2 - 7 } Komposisi & \multicolumn{2}{c}{ saji } & & & & \\
& $\begin{array}{c}\text { Formula } \\
\text { Kontrol }\end{array}$ & $\begin{array}{c}\text { Formula } \\
\text { Terpilih }\end{array}$ & $\begin{array}{c}\text { Formula } \\
\text { Kontrol }\end{array}$ & $\begin{array}{c}\text { Formula } \\
\text { Terpilih }\end{array}$ & $\begin{array}{c}\text { Formula } \\
\text { Kontrol }\end{array}$ & $\begin{array}{c}\text { Formula } \\
\text { Terpilih }\end{array}$ \\
\hline Energi (kkal) & 193,54 & 203,03 & 9,67 & 10,15 & 9,00 & 9,44 \\
Lemak (g) & 8,73 & 9,02 & 3,92 & 4,06 & 3,65 & 3,77 \\
Protein (g) & 4,14 & 4,24 & 0,82 & 0,85 & 0,77 & 0,79 \\
Karbohidrat (g) & 24,59 & 26,21 & 4,91 & 5,24 & 4,57 & 4,87 \\
Kalsium (mg) & 59,38 & 158,30 & 4,94 & 13,19 & 5,39 & 14,39 \\
\hline
\end{tabular}

Keterangan: *) \% AKG berdasarkan kebutuhan energi 2000 kkal dan kebutuhan kalsium 1200 mg

**) Kontribusi per takaran saji terhadap ALG (BPOM 2016) kelompok umum, kebutuhan energi 2150 kkal dan kebutuhan kalsium 1100 mg

Berdasarkan tabel 6, dalam satu takaran saji snack bar formula kontrol mengandung energi sebesar 193,54 kkal, lemak 8,73 gram, protein 4,14 gram, karbohidrat 24,59 gram, dan kalsium 59,38 miligram. Satu takaran saji (46 gram) snack bar formula kontrol memberikan kontribusi energi terhadap AKG sebesar 9,67\% dari total kebutuhan energi harian. Sedangkan dalam satu takaran saji snack bar tepung daun kelor formula terpilih mengandung energi sebesar 203,03 kkal, lemak 9,02 gram, protein 4,24 gram, karbohidrat 26,21 gram, dan kalsium 158,30 miligram. Satu takaran saji (46 gram) snack bar formula terpilih memberikan kontribusi energi terhadap AKG sebesar 10,15\% dari total kebutuhan energi harian. Hal ini menandakan bahwa mengkonsumsi satu takaran saji snack bar tepung daun kelor formula terpilih dapat memenuhi $10 \%$ kebutuhan energi dari makanan selingan dalam sehari.

\section{KESIMPULAN DAN SARAN}

Perbedaan konsentrasi subtitusi tepung daun kelor memberikan pengaruh pada hasil uji organoleptik hedonik terhadap atribut rasa, warna, dan aroma, namun tidak berpengaruh pada atribut tekstur. Hasil uji organoleptik mutu hedonik berpengaruh pada atribut warna. Formulasi snack bar terpilih adalah F2. Kadar proksimat berupa kadar air, kadar abu, lemak, protein, dan karbohidrat memiliki perbedaan yang nyata disetiap analisis. Snack bar formula terplih memperoleh klaim tinggi kalsium.

Diharapkan adanya penelitian lebih lanjut mengenai analisis penentuan umur simpan produk snack bar tepung daun kelor.. Hal lain yang perlu dilakukan adalah analisis 
pendugaan umur simpan produk dan analisis bioavailabilitas kalsium, untuk mengetahui jumlah kalsium yang dapat diserap oleh tubuh.

\section{DAFTAR PUSTAKA}

Afifah, N. N., \& Srimiati, M. (2020). Analisis Proksimat Snack Bar dengan Substitusi Tepung Pisang Kepok (Musa paradisiaca linn). Jurnal Ilmiah Kesehatan, 2(1): 36-42.

Aminah, Syarifah., Ramadhan, Tezar., dan Yanis, Muflihani. 2015. Kandungan Nutrisi dan Sifat Fungsional Tanaman Kelor (Moringa oleifera). Buletin Pertanian Perkotaan 5 (2): 35-44.

Arwani, M., Wijana, S., dan Kumalaningsih, S. 2019. Nutrient And Saponin Content of Moringa Oleifera Leaves Under Different Blanching Methods. International Conference on Green Agro-industry and Bioeconomy.

Beto, Judith A. 2015. The Role of Calcium in Human Aging. Clinical Nutrition Research.

Bey, Hakim. 2010. All Things Moringa. www.allthingsmoringa.com [Diakses tanggal 19 Oktober 2019]

BPOM RI. 2016. Peraturan Kepala Badan Pengawas Obat Dan Makanan Republik Indonesia Nomor 9 Tahun 2016 Tentang Acuan Label Gizi. Jakarta.

BPOM. 2016. Peraturan Kepala Badan Pengawas Obat dan Makanan Nomor 13 Tahun 2016 Tentang Pengawasan Klaim pada Label dan Iklan Pangan Olahan. Jakarta.

Darmawan, Eman. 2017. Daya Terima Konsumen Terhadap Bakpao Yang Diperkaya Sifat Fungsioal Serat dan Antioksidan Berbasis Daun Kelor (Moringa Oleifera). Agrotech 2 (1): 50-53.

Hardinsyah., Damayanthi, Evy., dan Zulianti, Wirna. 2008. Hubungan Konsumsi Susu dan Kalsium dengan Densitas Tulang dan Tinggi Badan Remaja. Jurnal Gizi dan Pangan 3 (1): 43-48.

Nurhiyanah, N. (2019). Substitusi Tepung Ampas Kelapa Dalam Pembuatan Brownies Kukus Terhadap Sifat Organoleptik Dan Nilai Gizi (Doctoral dissertation, Universitas Binawan).

Indriasari, Yuanita., Wignyanto., dan Kumalaningsih, Sri. 2016. Effect of Blanching on Saponins and Nutritional Content of Moringa Leaves Extract. Journal of Food Research 5 (3): 55-60.
J.Gipas, November 2020, Volume 4 Nomor 2

ISSN 2599-0152 eISSN 2599-2465

http://jos.unsoed.ac.id/index.php/jgps

Kemenkes RI. 2015. Data dan Kondisi Penyakit Osteoporosis di Indonesia. Jakarta.

Krisnadi, A. D. 2015. Kelor Super Nutrisi. PT Moringa Organik Indonesia. Blora.

Kurniawati, Indah., Fitriyya, Munaaya., dan Wijayanti. 2018. Karakteristik Tepung Daun Kelor Dengan Metode Pengeringan Sinar Matahari. [Prosiding] Seminar Nasional Unimus. Surakarta: Seminar Nasional Unimus.

Lyons, Sarah Joy., dan Wien, Anders Hauge. 2017. Evoking premiumness: How color-product congruency influences premium evaluations. Food Quality and Preference.

Mahmood, KT., Tahira, Mugal., dan Ikram, Ul Haq. 2011. Moringa oleifera: a natural gift-A review. Journal of Pharmaceutical Sciences and Research 2 (11): 775-781.

Majid, Frieda Rosita., Hidayat, Nur., dan Waluyo. Variasi Penambahan Tepung Daun Kelor (Moringa Oleifera Lam.) pada Pembuatan Flakes Ditinjau dari Sifat Fisik, Sifat Organoleptik dan Kadar Kalsium. Jurnal Nutrisia 19 (1): 31-35.

Mann Jim dan Truswell A. Stewart. 2014. Buku Ajar Ilmu Gizi Edisi 4. EGC. Jakarta.

Natalia, Daisy. 2010. Sifat Fisikokimia Dan Indeks Glikemik Berbagai Produk Snack. [Skripsi] Bogor: Institut Pertanian Bogor.

Noprisanti., Masrul., dan Defrin. 2018. Hubungan Asupan Protein, Kalsium, Phosfor, dan Magnesium Dengan Kepadatan Tulang Pada Remaja Putri Di SMP Negeri 5 Padang. Jurnal Kesehatan Andalas 7 (3): 29-36.

Nurjanah, Listi. 2017. Formulasi Torsang Snack Bar: Tepung Pisang dan Kacang Hijau dengan Penambahan Torbangun (coleus amboinicus Lour) sebagai Upaya Meringankan Keluhan Sindrom Pramenstruasi. [Skripsi] Bogor: Institut Pertanian Bogor.

Pratiwi, Fadhilah. 2018. Formulasi Food Bar Sumber Protein dan Kalsium Dari Tepung Daun Kelor (Moringa oleifera) dan Tepung Ikan Lele (Clarias gariepinus) untuk Dewasa Menengah. [Skripsi] Bogor: Institut Pertanian Bogor.

Pratiwi, Kadek Yuni. 2018. Pengaruh Substitusi Tepung Daun Kelor (Moringa oleifera) terhadap Karakteristik Biskuit Daun Kelor. [Skripsi] Bali: Poltekkes Denpasar.

Priyanto, Anugerah Dany., dan Nisa, Fithri Choirun. 2016. Formulasi Daun Kelor Dan Ampas Daun Cincau Hijau sebagai Tepung Komposit Pada Pembuatan Mie Instan. Jurnal Teknologi Pertanian 17 (1): 29-36.

Rousmaliana, R., \& Septiani, S. (2019). Identifikasi Tepung Ampas Kelapa Terhadap Kadar 
J.Gipas, November 2020, Volume 4 Nomor 2

ISSN 2599-0152 eISSN 2599-2465

http://jos.unsoed.ac.id/index.php/jgps

Proksimat Menggunakan Metode Pengeringan Oven. Jurnal Ilmiah Kesehatan, 1(1), 18-31.

Sari, Dewi Ayu Lintang. 2015. Pengaruh Penggunaan Lemak Yang Berbeda Terhadap Kualitas Cookies Tepung Garut (Maranta Arundinacea). [Skripsi] Semarang: Universitas Negeri Semarang.

Tionika, S. A. (2019). Identifikasi Tepung Kulit Pisang Kepok Terhadap Kadar Proksimat Menggunakan Metode Pengeringan Oven. Binawan Student Journal, 1(3), 131-136.

Setyaningsih, Dwi., Apriyantono, Anton., Maya, Puspita Sari. 2010. Analisis Sensoris Untuk Industri Pangan dan Agro. Bogor: Institut Pertanian Bogor.
Soraya, Netty. 2018. Studi Pembuatan Snack Bar Formula Tepung (Oat-Mocaf) dengan Fortifikasi Tepung Daun Kelor (Moringa oleifera). [Skripsi] Malang: Universitas Muhammadiyah Malang.

Syahwal, Sajiman., dan Dewi, Zulfiana. 2018. Pemberian Snack Bar Meningkatkan Kadar Hemoglobin $(\mathrm{Hb})$ pada Remaja Putri. Jurnal AcTion: Aceh Nutrition Journal 3 (1) 9-15.

Zakaria., Salmiah., dan Febriani, Vani Dwi Visca. 2011. Daya Terima Dan Analisa Komposisi Gizi Pada Cookies Dan Brownis Kukus Pandan Dengan Subtitusi Tepung Daun Kelor (Moringa Oleifera Lamk). Media Gizi Pangan 12 (2): 11-19. 